Guest editorial

\title{
Geomorphological research in Spain
}

\section{Introduction}

The production of this special issue arose from a successful scientific meeting held in Zaragoza, Spain (September 8-9, 2011), under the theme Geomorphological Research in Spain. The main motivation of the event was to recognize and celebrate the outstanding contribution carried out by Prof. Mateo Gutiérrez to the progress of Geomorphology in Spain, on the occasion of his transition to full-time research (Emeritus Professor). Mateo Gutiérrez (b. Burgos, 1941) was the President Founder of the Spanish Society of Geomorphology (1987) and led the organization of the Sixth International Conference of Geomorphology of the IAG (Zaragoza, 2005). With his enthusiasm and dedication, he has inspired and encouraged numerous geomorphologists, including ten $\mathrm{PhD}$ students, most of them nowadays working as professors or researchers in different institutions. In his prolific career, he has published more than 200 contributions, including a large number of papers dealing with a wide variety of topics, as well as numerous geological maps. Probably, the most relevant tangible contributions of Mateo Gutiérrez include the editorship of the book Geomorfología de España (Gutiérrez, 1994), and the authorship of the books Climatic Geomorphology (Gutiérrez, 2001, 2005) and Geomorfología (Gutiérrez, 2008). An expanded version of the latter, widely regarded as the reference Geomorphology textbook for Spanish-speakers, will be shortly published in English by Balkema (Gutiérrez, 2013). Since 2011, Mateo is Emeritus Professor at the University of Zaragoza, Spain.

The meeting Geomorphological Research in Spain was attended by around 65 participants, including several geomorphologists from Great Britain (Fig. 1). The opening lecture was presented by Prof. Adrian Harvey, who illustrated Mateo's contributions through some major themes for the Geomorphology of Spain. This stimulating keynote was followed by 40 oral presentations covering a wide geographical and thematic canvas. The second day was devoted to a field trip in Calatayud Graben, Iberian Chain, an area where Mateo has conducted extensive research. Here, we examined a seismogenic Quaternary fault and evidence of evaporite dissolution-induced subsidence, including severe structural damage in Calatayud city. Based on the presentations and the scope of the special issue, selected authors were invited to contribute to this special issue, which includes 18 articles out of the 28 initial submissions. In our opinion, this collection of papers illustrates the great potential of the Spanish geomorphology to learn lessons and develop methodologies applicable in other regions of the globe.

\section{General overview of the Spanish geomorphology}

Spain is the southernmost country in Europe and covers an area of 505,990 km², of which 12,465 $\mathrm{km}^{2}$ correspond to the Balearic Islands in the Mediterranean Sea, and the Canary Islands in the Atlantic Ocean. The Spanish territory has a remarkable geomorphological diversity largely due to its geological and climatic variability (Gutiérrez, 1994; Benito-Calvo et al., 2009). Moreover, the pressure on the environment caused by long-sustained human activity makes this country an excellent laboratory to investigate anthropogenic impacts on multiple geomorphic processes and landforms. The wide climatic variability is related to several geographical factors (Font, 1983; IGN, 
1995): (1) The territory covers a wide latitudinal range, from around $44^{\circ} \mathrm{N}$ in northern Spain, to $28^{\circ} \mathrm{N}$ in the Canary Islands, coinciding with the latitude of the Sahara Desert. The annual average precipitation in the eastern islands of the Canaries and in the southern leeward flank of the western islands may reach values below $100 \mathrm{~mm}$. (2) The Iberian Peninsula is located between the Atlantic Ocean and the Mediterranean Sea. A large proportion of the precipitation in Spain is related to fronts coming from the Atlantic Ocean that typically traverse the Peninsula from NW to SE. The annual precipitation in most of the northwestern sector of the peninsula exceeds $1200 \mathrm{~mm}$, whereas there is an extensive sector in the southeast where the yearly rainfall is below $400 \mathrm{~mm}$. The Gata Cape, Almería Province, has a mean annual precipitation of ca. 130 mm. (3) The topography of the Iberian Peninsula is characterised by a mosaic of morphostructural depressions (Cenozoic basins) and mountain belts (mostly Alpine orogens), some of which are located next to the coast, acting as barriers for moist air currents (Fig. 2). The sharp topographic contrasts, together with the orientation of the slopes with respect to the atmospheric circulation, determine striking temperature and precipitation gradients with a decisive imprint on the geomorphology. For example, the distance between some active glaciers in the Pyrenees and playa-lakes with wind-fluted yardangs and evaporite deposition in the semiarid Ebro Depression is just $150 \mathrm{~km}$. (4) Spain has the second highest mean elevation in Europe $(660 \mathrm{~m})$, after Switzerland. This overall high altitude is related to the extensive area covered by mountain ranges and the presence of extensive elevated plateaus (mesetas) in central Spain, corresponding to planation surfaces and structural surfaces. These topographic characteristics have a significant influence on some climatic features with geomorphological significance. The annual average number of days with temperature below to $0^{\circ} \mathrm{C}$ exceeds 120 days/yr in most of the mountain areas above $1200 \mathrm{~m}$ a.s.l. in the northern half of Spain, and is typically higher than 60 days/yr in the central mesetas. Another important characteristic of the Spanish climate, particularly in the Mediterranean fringe and the mountain regions, is the frequent occurrence of severe rainfall events which may have a dramatic geomorphic effectiveness and are responsible for the natural disasters with the highest number of fatalities (e.g. Gutiérrez et al., 1998; White and García-Ruiz, 1998; Ferrer et al., 2004; Ortega and Garzón-Heydt, 2009). The maximum daily rainfall for a return period of 50 years exceeds $100 \mathrm{~mm} /$ day in most of the mountain areas and reaches values above $200 \mathrm{~mm} /$ day in some sectors on the Mediterranean strip. The available records include a large number of rainfall events exceeding $400 \mathrm{~mm} / \mathrm{day}$, with top values higher than $800 \mathrm{~mm} /$ day (Martín-Vide, 2002).

An additional underlying reason why Spain has a great potential for geomorphological investigations is its outstanding geological diversity (Pérez-González et al., 1989; Gutiérrez, 1994; Gibbons and Moreno, 2002; Vera, 2004; Martín-Serrano, 2005). The Iberian Peninsula is commonly divided into two broad geological areas (Fig. 2A): (1) The Iberian Massif in the western sector, frequently regarded as Variscan Spain. (2) The Alpine mountain belts and Cenozoic basins of the eastern sector, related to the general $\mathrm{N}-\mathrm{S}$ convergence and collision between Europe, the Iberian microplate and Africa since the late Mesozoic.

The Iberian Massif is by far the most poorly known area of Spain from the geomorphological perpective. It is the best exposure of the European Variscan orogen, generated by the collision between Laurasia and Gondwana in the late Paleozoic. This 
structurally complex area mainly consists of Paleozoic metamorphosed sedimentary formations intruded by plutonic rocks, chiefly granitoids. The Mesozoic was a period dominated by erosion which led to the development of extensive peneplains. Compressional Alpine tectonics in this portion of Iberia has been accommodated by the development of intraplate mountain systems and small Cenozoic basins controlled by reverse and strike-slip faults, locally showing evidence of recent activity (e.g. MartínGonzález, 2009). The $700 \mathrm{~km}$ long and ENE-WSW trending Central System, corresponds to an uplifted portion of the Variscan basement bounded by double-verging reverse faults. This Alpine pop-up morpho-structure separates the Duero and Tajo Cenozoic basins in central Spain and reaches $2592 \mathrm{~m}$ in elevation. One of the most characteristic features of the landscape in the Iberian Massif is the presence of planation surfaces, which may form extensive plains locally interrupted by residual reliefs (monadnocks), or occur as concordant flat summits. The mature topography of this relatively stable area has favoured the development and preservation of thick paleoweathering profiles that record past climate conditions and constitute a valuable correlation tool for regional geomorphology (Molina et al., 1997; Martín-Serrano and Molina, 2005). Another characteristic feature of the Iberian Massif is the presence of extensive piedmont alluvial deposits composed of siliceous clasts with a reddish argillaceous matrix (raña). These thin alluvial mantles situated above the terrace sequences and of supposed late Neogene age, record the initial phases of development of the present-day drainage network (Martín-Serrano, 1991; Molina-Ballesteros and Cantano-Martín, 2002). Some of the most striking geomorphological features in the Iberian Massif are related to the underlying lithology and structure. In some areas, differential erosion of folded Paleozoic rocks with contrasting resistance to erosion (e.g. quartzites and slates) has produced a distinctive Appalachian-type of topography. Some areas of Galicia and the Central System display spectacular examples of granite geomorphology with bornhardts (e.g. La Pedriza de Manzanares), tors, fields of corestones, etch surfaces and tafoni with speleothems. The best example of karst geomorphology in the Iberian Massif is found in the Picos de Europa Massif, with peculiar depressions of mixed karstic and glacial origin, shaft-dominated caves more than $1.5 \mathrm{~km}$ deep, and gorges with impressive walls more than $1 \mathrm{~km}$ high. The glaciated areas are restricted to the highest massifs in the central and northern sectors of Iberian Massif. A peculiar feature is the development in the late Pleistocene of ice caps on the planated summits of some mountain ranges, linked to radiating outlet glaciers (Cowton et al., 2009; Carrasco et al., 2012).

The Betic Chain and the Pyrenees are Alpine orogens resulting from the collision of the Iberian microplate with the European and African plates, respectively. These are the mountain belts with highest peaks in mainland Spain. The Mulhacén in the Betics and the Aneto in the Pyrenees, have elevations of 3,482 $\mathrm{m}$ and 3,404 m a.s.l., respectively. The Pyrenees is essentially a plate margin with negligible relative motion, whereas the Betics is currently affected by considerable convergence and tectonic activity. One of the main geomorphic differences between these Alpine collision orogens and the rest of the intraplate mountain belts in Spain is the lack of extensive planation surfaces, attributable to rapid deformation in a plate margin context.

The Betics, with a general NE-SW orientation, extends for about $1000 \mathrm{~km}$ in the south and southeast of Spain, including the Balearic Islands. The Inner Zone of the Betics is dominated by structurally complex and metamorphosed basement and cover rocks forming an antiformal stack, interpreted as an accreted terrane (Alborán microplate). 
The Outer Zone is essentially a suite of alloctonous south-verging structural units made up of Mesozoic and Cenocoic sedimentary sequences detached from the Variscan basement. The Betic Chain also includes numerous postorogenic Late MioceneQuaternary basins whose development is related to the general N-S compression associated with the ongoing convergence between Africa and Iberia. Most of these basins record a transition from marine to continental deposition and some of them are currently affected by tectonic inversion. The Betics is clearly the best region in Spain to investigate the impact of active tectonics on landscape development. It includes excellent examples of fault-controlled mountain fronts and alluvial fan systems (e.g. Silva et al., 2003), whose development may be affected by multiple factors like tectonic activity, climate variability and base level changes (Harvey et al., 1999). A number of studies conducted in this region illustrate the crucial role played by geomorphological studies in the identification of faults and the assessment of their seismogenic potential (e.g. García-Tortosa et al., 2011). In the Betic Chain, the evolution of the drainage network, largely guided by the postorogenic basins, has been the focus of pioneering studies addressing issues like the impact of capture induced base-level changes (Goy et al., 1994; Harvey and Wells, 1987; Mather, 2000; Maher et al., 2007; Whitfield and Harvey, 2012), the transition of alluvial fan systems into fluvial systems (Silva et al., 2008), the impact of active faulting and folding on transverse drainages (Maher and Harvey, 2008) or the morpho-stratigraphic record of incision waves (García et al., 2003). These investigations reveal the need for a regional approach for examining longterm changes in fluvial systems. Limestone karst is well-developed in numerous regions, mostly of the Outer Betics, with magnificent examples of poljes controlled by active faults (e.g. Zafarraya Polje; Lhenaff, 1986; Reicherter et al., 2003), karren fields (Torcal de Antequera, Tramuntana Range) and cave systems, some of them with significant economic (Nerja show cave), engineering (Hundidero Gato Cave and the failed Montejaque Dam project) and paleoanthropological (Finlayson et al., 2006) implications. Landforms related to evaporite dissolution are mainly developed on halokinetic Triassic halite-bearing evaporites (Calaforra and Pulido-Bosch, 1999) and in the Messinian gypsum of Sorbas Basin, with a peculiar stratigraphically-controlled multilevel cave system, mainly carved in argillaceous units (Calaforra and PulidoBosch, 2003). Evidence of Quaternary glaciation is restricted to Sierra Nevada, which is the southernmost glaciated area in Europe. Here, valley glaciers reached just around 3 $\mathrm{km}$ in length during their maximum extent, which apparently occurred before the global Last Glacial Maximum. Rock glaciers have been reported at the foot of the headwalls of some cirques (Gómez-Ortiz et al., 2012). The spatial distribution of large landslides in the Betics is mainly controlled by litho-structural factors, active tectonics and fluvial incision (Gelabert et al., 2003; Azañón et al., 2005; Delgado et al., 2011) and, unlike the Pyrenees, debutressing related to deglaciation has a negligible impact.

The Pyrenean orogen, with a prevalent E-W structural and topographic grain, extends for around $650 \mathrm{~km}$ in northern Spain, including the eastern portion of the Cantabrian Cordillera underlain by post-Variscan sequences affected by contractional structures. In this collisional plate margin, the orogenic phase and the inversion of post-Variscan basins took place from late Cretaceous to Miocene times. The Spanish sector of this double-verging mountain belt can be divided into two main structural units. The Axial Pyrenees, in the core of the orogen, constitutes an antiformal stack made up of Variscan basement. The Southern Pyrenean zone is an allochtonous system of south-verging thrusts, mostly affecting post-Variscan sucessions, and locally including Paleogene sequences deposited in former forelands basins incorporated into the orogene. The 
topography shows a general decrease in elevation from the axial zone, with peaks above $3000 \mathrm{~m}$, towards the southern margin of the orogenic wedge. The regional geomorphology of the Pyrenees is dominated by differential erosion processes controlled by the E-W structure, and N-S glacial-fluvial transverse valleys coherent with the general topographic trend. Differential erosion of erodible sediments, mostly Paleogene argillaceous formations and Triassic clays and evaporites, has generated broad E-W trending erosional depressions which display the best developed pediment and terrace sequences. The transverse drainages have carved deep and narrow valleys with local widenings associated with less resistant lithologies. In great part of the Pyrenees, the headwaters of the catchments were occupied by valley glaciers in the late Pleistocene, which reached the maximum extent well-before the global Last Glacial Maximum (García-Ruiz et al., 2003, Jiménez-Sánchez et al., 2012). In the central Pyrenees, the valley glaciers, in some cases more than $500 \mathrm{~m}$ thick and $30 \mathrm{~km}$ long, reached elevations below $900 \mathrm{~m}$ a.s.l. In the more humid Cantabrian Mountains the front of some paleoglaciers has been situated below $500 \mathrm{~m}$ a.s.l. These alpine glaciers carved cirques, over-deepened basins and deep troughs with steep slopes. Locally, lateral moraines blocked tributary drainages generating marginal enclosed basins with lacustrine deposition. In some valleys it has been possible to establish chronological associations between frontal moraines and outwash terraces and identify older glacial phases on the basis of morpho-stratigraphical relationships and geochronological data (Lewis et al., 2009; Jiménez-Sánchez et al., 2012). At the present time, there are about 20 cirque glaciers restricted to massifs higher than $3000 \mathrm{~m}$ a.s.l. in the central Pyreenes. These glaciers expanded during the Little Ice Age, as revealed by historical data and fresh moraines, and are currently affected by rapid recession (Chueca-Cía et al., 2005). Periglacial activity is represented by both active and relict talus slopes, rock glaciers (Serrano et al., 2010) and patterned ground.

Landslides in the Pyrenees constitute a major morphogenetic process and, together with flooding, is the main geomorphical hazard. A number of villages have been destroyed or abandoned due to landslide activity (Inza, Salinas de Jaca, Puigcercós, Montclús, Pont de Bar). In glaciated valleys with unstable lithologies, deep-seated landslides related to the debutresing of oversteepened slopes may display very high spatial frequencies (Guerrero et al., 2012a). The development of most of the large landslides is favoured by litho-structural factors, like the presence of thick halite bearing evaporites (Gutiérrez et al., 2012), or the favourable attitude of the strata (Pinyol et al., 2012). In addition to glacial debutressing, fluvial erosion, severe precipitation (Corominas and Moya, 1999), and seismic shaking (e.g. González-Díez et al., 1999; Gutiérrez et al., 2008a; Rosell et al., 2010) are the main natural triggering factors. The occurrence of shallow landslides and debris flows has been largely influenced by changes in land use and land cover (e.g. Martí et al., 1997; Remondo et al., 2005; Beguería, 2006; García-Ruiz et al., 2010). Changes in plant cover have a large influence on the magnitude and frequency of floods, erosion and sediment transport. Plant colonization after farmland abandonment resulted in a progressive decline in the number of floods and in the sediment yield at both small catchment (García-Ruiz et al., 2010) and regional scales (Beguería et al., 2006). Floods have a particularly severe geomorphic and societal impact in relatively small and steep drainage basins, were catastrophic flash floods related to convective storms may develop in a very short period of time. The 1996 Arás flood caused 87 fatalities in a campground built in the active lobe of an alluvial fan, fed by a drainage basin around $18 \mathrm{~km}^{2}$ in area and $1200 \mathrm{~m}$ in relief (White et al., 1997; Gutiérrez et al., 1998). 
The Outer Zone of the Pyrenees, with thick limestone sequences, includes some of the most remarkable karst massifs in Spain with doline and karren fields, poljes frequently with vague structural control, deep canyons, ponors and springs, as well as caves with large vertical development (Arañonera Cave, $1350 \mathrm{~m}$ ). Evaporite karst features mainly correspond to lake basins developed in collapse structures related to dissolution of subjacent Triassic and Eocene formations (Estaña, Montcortés, Bañolas; e.g. Canals et al., 2006; López-Vicente et al., 2009). Moreover, numerous dam projects have been severely affected by karst-related water leakage problems (Belsué, Canelles, Camarasa; Milanovic, 2000).

The Iberian Chain and the Catalan Coastal Chain in NE Spain are intraplate Alpine orogens resulting from the tectonic inversion of Mesozoic basins during the Paleogene. During the Neogene, extensional tectonics generated horsts and graben morphostructures superimposed on the previous contractional structures. The Neogene grabens in the Iberian Chain are filled by alluvial and lacustrine sediments, whereas those of the Catalan Coastal Chain may include marine sequences. The Mesozoic successions have a high proportion of limestone units that form extensive outcrops. The Iberian Chain, with a general NW-SE trend is a broad elevated area $400 \mathrm{~km}$ long and $200 \mathrm{~km}$ wide. The Catalan Coastal Chain, with a NE-SW orientation, extends obliquely for about $200 \mathrm{~km}$ along the Meditarranean coast. This mountain chain displays a conspicuous horst and graben topography consisting of two ranges (Littoral Cordillera and Pre-littoral-Cordillera) separated by an axial graben system (Pre-littoral Depression). One of the most outstanding geomorphological characteristics of these orogens, especially the Iberian Chain, is the presence of extensive planation surfaces cut across deformed pre-Neogene rocks, chiefly Mesozoic carbonate rocks (Gutiérrez and Peña, 1994). This general plateau-like topography is locally interrupted by monadnocks, frequently underlain by more resistant Paleozoic rocks, neotectonic grabens, erosional depressions and fluvial valleys. The flat topography developed on carbonate rocks has favoured the development of doline fields (Gutiérrez and Peña, 1979), karren and poljes, generally controlled by faults (e.g. Gracia et al., 2003). Pleistocene glaciers were restricted to cirques carved in the hard-rock massifs higher than $2000 \mathrm{~m}$ located in the northern and central sector of the Iberian Chain. In the high country, active and relict periglacial features are relatively abundant, including nivation cirques, protalus ramparts, rock glaciers, patterned ground, grèzes litées, and remarkable block streams (e.g. Gutiérrez and Peña, 1977). The drainage network in the central sector of the Iberian Chain is largely controlled by the post-orogenic grabens and records the successive capture of different tectonic depression by headward expansion (Gutiérrez et al., 2008b). The horst and graben topography of the Catalan Coastal Range is crossed perpendicularly by major transverse drainages (Arche et al., 2010). In the outcrops of limestone-rich Mesozoic successions, streams typically flow deeply entrenched in canyons with frequent tufa accumulations (Vázquez-Urbez et al., 2011). Both, the Iberian Chain and the Catalan Coastal Chain have good examples of tectonic landforms associated with active normal faults, like mountain fronts, triangular facets and disrupted drainages (Perea et al., 2012; Zarroca et al., 2012). In the northern sector of the Catalan Coastal Chain there are basaltic volcanic fields controlled by post-orogenic normal faults. The Garrotxa area includes more than 40 nicely preserved Late Pleistocene cones developed by strombolian and phreatomagmatic eruptions (Martí et al., 2011). Also in the northern sector of this chain there are extensive inliers of Variscan basement with good examples of landforms related to surface and subsurface 
granite weathering (Roqué et al., 2011). The Catalan Coastal Chain, forming a topographic barrier adjacent to the Mediterranea Sea, is one of the most prone areas in the Spain to the occurrence of flash floods and rainfall-triggered landslides (e.g.

$$
\text { I. }
$$
Vilaplana, 2008; Llasat et al., 2010).

Spain has four large Cenozoic basins that cover around one third of the country area. These morphostructural depressions control the path of the main fluvial systems, from which they receive their names; Ebro, Duero, Tajo and Guadalquivir basins. The formation and development of these sedimentary basins have been mainly controlled by the tectonic evolution of the surrounding Alpine orogens and, in the case of the Ebro, Duero and Tajo basins, by the capture of the depressions and the progressive change from endorheic-aggradational to exorheic-incisional conditions. The Ebro and Guadalquivir depressions are foreland basins of the Pyrenees and Betic Chain, respectively. The Duero and the Tajo depressions are essentially intracratonic structures bounded by Alpine contractional structures. The ENE-WSW Guadalquivir Basin has been open to the sea during its entire evolution and the Miocene-Quaternary fill mainly consist of marine sediments. The southern half of the basin is dominated by olistostromes made up of chaotic Mesozoic and Cenozoic rocks, whereas the northern half is mainly underlain by autochthonous soft marly sediments. The upper and middle reach of the Guadalquivir valley, currently abutting the rectilinear northern margin of the basin, displays an extensive terrace sequence on the southern margin (Díaz del Olmo et al., 1989; Baena and Díaz del Olmo, 1997). In the lower reach, the river splits into several anastomosed channels flowing through an extensive marshland separated from the sea by a long spit bar with a large superimposed dune field (Doñana National Park). The growth of the spit bar has induced the rapid siltation of the marshland after the Flandrian transgression and the shifting of the river channel to the SE (REF?). The Ebro, Duero and Tajo basins have relatively similar sedimentary and geomorphic evolutions. Most of the outcropping sediments in these depressions are Oligo-Miocene continental formations with subhorizontal structure deposited under endorheic conditions. These sediments typically display a roughly concentric facies distribution, with conglomerates at the margins that grade distally to fine-grained alluvial fan facies, and lacustrine evaporites and carbonates in the depocentral sectors. The end of the endorheic fill is commonly recorded by Miocene limestone units which may connect, physically or altitudinally, with planation surfaces at the basin margins (e.g. BenitoCalvo and Pérez-González, 2007). These endorheic basins were captured in the Miocene by the external drainage network. The new exorheic conditions lead to the development of the present-day drainage network responsible for the dissection of the sedimentary fill and the development of stepped pediment and terrace sequences. The oldest exorheic morpho-sedimentary units typically correspond to extensive and prominent mantled pediments (e.g. rañas) that record unconfined alluvial-fluvial systems developed before the entrenchment of the fluvial systems and the formation of staircased terraces (e.g. Martín-Serrano, 1991; Lucha et al., 2012). The landscape within these Cenozoic basins is largely influenced by the distribution of lithofacies. The marginal conglomerates form elevated areas and locally stunning monoliths more than $300 \mathrm{~m}$ high with precipitous cliffs controlled by vertical fractures (e.g. Riglos and Montserrat in the Ebro basin). Erosional depressions with extensive mantled pediments and bandland landscapes occur in the areas dominated by argillaceous facies. The limestone units cap buttes, mesas and structural platforms with fields of shallow solution sinkholes. The reliefs formed by relatively thin limestone caprocks underlain by erosible sediments are frequently surrounded by sequences of talus flatirons
Con formato: Inglés

(Reino Unido) 
(Gutiérrez-Elorza et al., 2010). The Ebro and Tajo basins have thick halite- and glauberite-bearing evaporitic units. In these areas the alluvial deposits are locally thickened recording dissolution-induced synsedimentary subsidence (Benito et al., 2010; Guerrero et al., 2012b; Silva et al., 2012). In these areas, sinkholes may show a high activity in the most densely populated lower alluvial levels, resulting in high risk scenarios (Galve et al., 2009). Eolian activity has a significant geomorphic imprint in the southern sector of the Duero basin, where the bedrock is dominated by friable arkosic sandstones and the fluvial systems are mainly nourished by sands. Here, there are extensive sand sheets, dune fields (Bateman and Díez, 1999; García-Hidalgo et al., 2007; Bernat-Rebollal and Pérez-González, 2008), and abundant deflation basins; pans and blowouts (Gutiérrez-Elorza et al., 2005). In the Ebro Basin, where there is very limited availability of sands, eolian accumulations are very scarce, but the strong wind has carved yardangs on gypsiferous rocks and unconsolidated lake deposits in the leeward margin of playa-lakes (Gutiérrez-Elorza et al., 2002). Another common feature of the Cenozoic basins is the occurrence of endorheic areas that may host ephemeral saline lakes. Subsurface evaporite dissolution and eolian deflation are generally the main processes involved in their genesis.

An additional geological unit in Spain is the Canarian Archipelago, a chain of hot-spot related volcanic islands that extends for around $500 \mathrm{~km}$ across the eastern Atlantic. These islands have grown upon the slow moving Jurassic oceanic lithosphere next to the passive margin of the African plate. The Cenozoic volcanic sequences, dominated by basaltic rocks, record a long period ( $>20 \mathrm{Ma}$ ) of eruptive activity, from the early built up of submarine sea mounts to the polyphasic development of volcanic edifices, eventually affected by giant landslides. The islands constitute steep piles of volcanic rocks raising several kilometres above the abyssal plain, with less than $10 \%$ of the volume emerged above the sea. The Teide stratovolcano in Tenerife is the highest peak in Spain (3.718 m a.s.l.), with more than $7 \mathrm{~km}$ in relief with respect to the adjacent abyssal plain. Long-sustained subaerial volcanism has produced large volcanoes with subcircular base or elongated ridges where the emission of magma is controlled by persistent fractures. A total of 18 historical eruptions have been documented over the last 500 years. The penultimate event was the 1971 Teneguía volcano eruption in La Palma, and the most recent event the 2011 submarine eruption of El Hierro. The 17301736 eruption of Timanfaya, Lanzarote, is the second largest basaltic fissure eruption documented in historical time. It lasted for more than 2000 days and eruptive activity from a $14 \mathrm{~km}$ long fissure produced more than 30 cones and lava flows covering around $200 \mathrm{~km}^{2}$, over $20 \%$ of the island (Carracedo et al., 1992). The areas affected by recent volcanic activity are dominated by poorly dissected lava fields and cones (RodríguezGonzález et al., 2012). Lava tubes and sinkholes resulting from the collapse of their roofs, locally designated as jameos, are relatively frequent in some sectors. The $17 \mathrm{~km}$ long Viento-Sobrado Cave, Icod de los Vinos, Tenerife, is the largest lave tube in the European Union. The old massifs are characterised by a deeply entrenched drainage network (Menéndez et al., 2008) and landforms related to differential erosion like volcanic necks and protruding dykes. A striking feature in the Canaries are the giant landslides related to the gravitational collapse of volcanoes, favoured by the continuous growth of the edifices, the presence and injection of dykes, and pressurized fluids (Cendrero and Dramis, 1996; Masson et al., 2002; Hürlimann et al., 2004). These mass movements, with an estimated frequency of 125-170 ka, are expressed as huge arquate escarpments and chaotic landslide deposits, mostly accumulated in the sea floor, which may exceed $1000 \mathrm{~km}$ in length (Urgelés et al., 1997). The development of these 
structural collapses may cause dramatic changes on the magma feeding system and influence the subsequent volcanic and geomorphic evolution of eruptive complexes (Boulesteix et al., 2012)

An outstanding asset of the Spanish geomorphology is the extent and diversity of the coastal environments, with ca. 8,000 km of coastline surrounding mainland Spain, as well as the islands of the Canarian and Balearic archipelagos. The main factors that control the geomorphology and Quaternary geology of the Spanish coasts include (Goy and Zazo, 2005): (1) Eustatic changes; in the last glacial cycle, at ca. $18 \mathrm{ka}$, the sea level dropped more than $100 \mathrm{~m}$ below the present-day position, favouring the development of extensive eolian accumulations (Sanjaume and Gracia, 2011). (2) Litho-structural factors, including substantial vertical neotectonic deformation in numerous sectors. (3) Geographic location between the European and African continents and the Atlantic and Mediterranean basins, both connected from the Early Pliocene through the Strait of Gibraltar. (4) Tidal range. (5) Relative orientation of prevailing winds and the coastline. (6) Human activity, chiefly the construction of coastal structures and dams in the drainage basins that have modified sedimentation and erosion patterns. A remarkable feature of the Spanish coasts is the presence of good sequences of marine terraces and alluvial fans associated with areas affected by neotectonic uplift, which constitute excellent records of sea level change and valuable markers to identify an assess recent tectonic deformation (e.g. Zazo et al., 2003, 2012). The geomorphology of the coasts in the Mediterranean, including the Balearic Archipelago, are largely determined by the distribution of areas affected by positive and negative vertical tectonics and the microtidal regime (range below $50 \mathrm{~cm}$ ). The subsiding areas are characterised by lakes and lagoons associated with spit bars and dune systems related to the Flandrian transgression (ca. $6.5 \mathrm{ka}$ ), as well as beach-ridge progradational complexes (Goy et al., 2003). The uplifting sectors are dominated by Plio-Quaternary sequences of alluvial fans and marine terraces, as well as rock cliffs. These coasts also include deltas related to the progradation of fluvial systems after the Flandrian transgression, largely influenced by human activity in the last centuries (e.g. Lario et al., 1995). The geomorphic features of the Atlantic coast in the Gulf of Cadiz are largely controlled by the distribution of the different geological units and the presence of active faults with different orientations with respect to the coastline. In the Cenozoic Guadalquivir Basin, the low relief coast has extensive estuaries and marshes associated with the lower reach of the main rivers, partially closed by spit bars up to $30 \mathrm{~km}$ long and large dunes fields (Borja et al., 1999; Zazo et al., 1999). The Atlantic coast developed on the Betics has a strong structural control and displays good sequences of raised marine terraces and cliffs interrupted by small bays and coves. The most relevant landforms in the Atlantic coast of northern Spain are the Galician rías (deep fluvial valleys partially submerged by the sea; Pagés-Valcarlos, 2000), estuaries (Flor and Flor-Blanco, 2006), rock cliffs and stepped sequences of rasas (Álvarez-Marrón et al., 2008). The latter correspond to flat surfaces cut across bedrock perched up to several hundred meters above the sea level and locally covered by a thin veneer of deposits.

\section{Geomorphological investigations in Spain through the journal Geomorphology}

In order to analyse some aspects of the geomorphological research in Spain with international projection over the last two decades, we have identified all the papers dealing with this country published in the journal Geomorphology, since the release of the first issue in 1987. Geomorphology, which is the most referenced international journal of the subject, may be considered as a good source of information to infer some 
of the main patterns of the geomorphological research carried out in the Spanish territory. We have compiled a list of 241 papers, including the 18 articles of this special issue and those available on line as in press (see online Supplementary Material). These contributions, dealing with geomorphological investigations carried out in Spain regardless of the nationality and affiliation of the authors, represent $5.5 \%$ of the papers published in Geomorphology (4385 in October 2012). Around 64\% of the papers are authored by 1 to 4 people. Regarding the affiliation of the senior authors, $78.4 \%$ and $10.4 \%$ of the papers were led by geomorphologists based in Spain and in the UK, respectively. Around half of the latter ones (13 papers) are related to the prolific research activity developed by Adrian Harvey and his former students (Mather and Stokes, 2003; Plater and Lang, 2008). Belgium and The Netherlands, with 6 papers each, represent separately $2.5 \%$ of the total, and the rest of the countries have four or less papers.

The first paper dealing with Spain published in the journal Geomorphology dates back to 1994; i.e. 8 years after the first issue was released. Figure 3 shows the number of papers related to Spain published from 1995 to 2010, grouped into 4-years-long periods. The amount of papers shows a rapid increase in the last decade, from 28 and 29 papers published in 1995-98 and in 1999-2002, respectively, to 69 articles produced in 200710. A similar trend was observed by García-Ruiz (1999) for the number of papers published by Spanish authors in the main international geomorphological journals during the 1990's decade. This rise in productivity may be attributed to several factors: (1) Increase in the number of people working on geomorphology-related topics and amount of economic resources devoted in previous years to research, in general, and geomorphological projects, in particular. Fortunately, the perception of Geomorphology as an instrumental subject to understand and solve multiple environmental problems is augmenting. Moreover, there is an increasing number of geologists that are reorienting their investigations from the study of old geological features to more practical active surface processes and recent geological records. (2) The evaluation of the scientific production in Spain is largely based on the number of papers published in international journals included in the Journal Citation Reports of the ISI Web of Knowledge. (3) The publication of a collection of 14 widely quoted papers in the special issue Long-term landscape development in Southern Spain, edited by Mather and Stokes (2003). Unfortunately, the continuous cuts in the government budget devoted to research and development (4\%, 7\% and 25.5\% in 2010, 2011 and 2012, respectively) will have a negative impact on the geomorphological production in Spain. In fact, many of the advances achieved over the last decades, including the creation of research groups and the training of ground-breaking researchers, are being spoiled in a few years (MoroMartín, 2012; Pain, 2012).

The 241 papers have been grouped into the following general subjects: Regional geomorphology, Neotectonics, Karst, Volcanism, Weathering and soils, Soil erosion, Slopes and landslides, Fluvial-alluvial, Coastal-marine, Lakes, Eolian, Glacial, Periglacial, and Environmental geomorphology (Fig. 4A). Just two themes, Fluvialalluvial (53 papers) and Soil erosion (46 papers), account for $41 \%$ of the contributions. The categories Slopes and landslides (34 papers) and Coastal-marine (26 papers) represent $14 \%$ and $11 \%$, respectively. Other frequently addressed topics include Neotectonics (17 papers, 7\%), Karst (15 papers, 6\%) and Weathering and soils (14 papers, 6\%). A striking feature regarding the karst papers is that more than half of them are related to evaporite karst; outcrops of these rock types cover around $7 \%$ of the 
country area. García-Ruiz (1999) reached similar findings analysing the geomorphological scientific production in Spain up to 1998 considering a large number of local and international publications. The most outstanding discrepancy is that in that bibliometric analysis, which included national publications, Glacial geomorphology was the third topic with the largest number of articles, whereas in the journal Geomorphology it only represents $4 \%$.

To analyse the geographical distribution of the contributions related to Spain, the papers have been grouped considering the following main geological units (Fig. 4B): the Iberian Massif in the western Iberian Peninsula, the volcanic Canary Islands, the main Cenozoic basins (Ebro Basin, Duero Basin and Tajo Basin), and the Alpine orogens, including the Pyrenees, the Catalan Coastal Ranges, the Iberian Chain, the Central System and the Betics. The latter zone incorporates the Guadalquivir Basin because some investigations overlap both regions. The Pyrenees embraces all the ranges related to the Alpine orogeny in northern Spain, including the eastern Cantabrian Mountains. An additional category corresponds to Spain, ascribed to papers dealing with the whole country or several geological units. By far, the area where the highest proportion of investigations published in Geomorphology has been developed corresponds to the Betics, with 101 papers (42\%). Around half of these papers correspond to the Fluvialalluvial and Soil erosion thematic groups. Well behind are the Pyrenees (31 papers) and the Ebro Basin (28 papers). The most frequent topics in the Pyrenees are Slopes and landslides, Soil erosion and Fluvial-alluvial, whereas in the Ebro Basin the Fluvialalluvial and Karst thematic groups prevail. The rest of the articles of each area represent less than $10 \%$.

\section{The papers of the special issue}

The eighteen papers of this special issue cover a wide breadth of topics and regions in Spain. The first two articles provide valuable reviews on the geomorphology of the Iberian continental margin and the Quaternary history of sea level change in Spain. Maestro et al. present an overview of the geomorphology of the continental margin and the abyssal plains around the Iberian Peninsula. The studied area, covering approximately 2.3 million $\mathrm{km}^{2}$ of the seafloor, has a great diversity of morphologies, largely related to the complex geology of the Iberian Peninsula and its location between the Atlantic Ocean and the Mediterranean Sea. It includes striking features like various morpho-structures related to salt flowage, mud volcanoes, pockmarks, volcanic seamounts, contourite drifts, moats and channels, submarine canyons and channels up to $400 \mathrm{~km}$ long, turbidite systems as much as $350 \mathrm{~km}$ across, debris flows $100 \mathrm{~km}$ long. The distribution of the geomorphic features, classified into structural (tectonic and volcanic), depositional and erosional, is analysed in relation to morphotectonic and oceanographic factors. The paper is accompanied by a ground-breaking "Geomorphological Map of the Iberian Continental Margin at 1:2,000,000 scale" downloadable as supplementary material. Zazo et al. reviews the morpho-stratigraphic record of Quaternary sea level changes in the Mediterranean and Atlantic coast of Spain, including the Canary Islands. The coastal geomorphic responses to sea-level changes with different temporal frequencies are illustrated through the best preserved and most complete morpho-stratigraphic sequences, covering a wide range of geodynamic contexts (tectonically active and stable) and integrating the spatial relationships between marine and terrestrial records. 
The following three papers deal with the spatial and temporal evolution of glaciers in different mountain regions of northern and central Spain. The presented geochronological data strongly support that glaciation in the last cycle peaked much earlier than the global Last Glacial Maximum of MIS2. Jiménez-Sánchez et al. review the history of glacial research in the mountains of northern Spain (Pyrenees and Cantabrian-Galician mountains) and analyse the available information on the timing and extent of Pleistocene glaciations, with special focus on the last local glacial maximum. The numerical ages obtained in diverse settings and by means of multiple techniques demonstrate that, in northern Spain, the maximum extent of the ice in the last glacial cycle occurred well before the global LGM of MIS 2 (18-21 ka). The more abundant geochronological data from the Pyrenees indicate a local glacial maximum between 50 and 70 ka in MIS 4. Moreover, they report morphostratigraphic evidence and numerical ages (OSL, cosmogenic surface exposure) recording previous glacial cycles during MIS6 and MIS8, in which glaciers covered more extensive areas than in the last maximum ice extent. Serrano et al. presents a novel reconstruction of the late Quaternary glacial evolution in the central Cantabrian Mountains (N Spain) based on geomorphological mapping, paleo-ELA estimations and numerical dating. They identify four main glacial stages in these Atlantic mountains, characterised by markedly different precipitation between the northern side (ocean-facing) and the southern one (precipitation shadow). Glaciers reached the maximum extent before the global LGM. The second stage, also older than the LGM, is tentatively situated in the MIS3 to MIS2 transition or in MIS2. The third stage is ascribed to the Tardiglacial (14-15 ka). The most recent one, corresponding to the Little Ice Age and restricted to the highest massifs, is documented by historical records. Carrasco et al. present a 3D reconstruction of the ice mass during its maximum extent in the Bejar Range, Central System, based on detailed geomorphological mapping and physical models. At this stage, dated at ca. $27 \mathrm{ka}$ by ${ }^{10} \mathrm{Be}$, the planated summit of the range was capped by a plateau glacier up to $120 \mathrm{~m}$ thick, linked to radiating outlet glaciers that reached a minimum elevation of $1220 \mathrm{~m}$ a.s.l. During the deglaciation, the dome-shaped icecap evolved into an icefield eventually disconnected from the valley glaciers. This piece of work provides valuable data on the Late Pleistocene evolution of a highly sensitive paleoglacier located in a low latitude Mediterranean area with both Atlantic and continental influence.

An innovative concept on the development of tafoni on granitoids is proposed by Roqué et al. in the Catalan Coastal Chain. These authors infer subsurface meter-sized spheroidal pockets of weathered granite, as revealed by low resistivity anomalies in electrical resistivity tomography (ERT) profiles and hyperbolic diffractions in radargrams acquired by ground penetrating radar (GPR). The spatial association of these underground features with tafoni of similar sizes and geometries at the surface leads the authors to propose a new genetic model for these controversial landforms. Tafoni development may be initiated in the subsurface by preferential weathering related to groundwater flows controlled by fractures. Erosion enhances groundwater flow by unloading the rock mass and dilating fractures and eventually leads to the exposure of the weathering pockets evolving into tafoni. Whitfield et al. analyse the impact of Quaternary environmental change on the evolution of the Bergantes River, Iberian Chain, recorded by a sequence of six terrace levels. The stratigraphy and sedimentology of the terrace deposits, together with geochronological data, allow the differentiation of two periods with contrasting fluvial behaviour. The two oldest Pleistocene terraces, 
ascribed to glacial conditions, record major aggradation phases with significant sediment supply from tributary drainages and hillslopes. The four youngest terraces represent small and short-duration cut and fill cycles characterised by limited sediment supply, mostly related to the trunk river. These cycles are attributed to stadial (aggradation) and interstadial (incision) phases occurred over the last $25 \mathrm{ka}$. The inferred evolution reveals that in high sensitivity fluvial systems, like the Bergantes River catchment in semiarid Spain, incision and aggradation patterns may be controlled by both orbital- and suborbital-scale climate changes, which determine variations in vegetation and sediment supply. Ortega et al. analyse the evolution of the Las Torcas multilevel cave system in Atapuerca Range (Iberian Chain), which host most important homind-bearing archeo-paleontological sites in Europe. Detailed mapping of the subhorizontal passages and geomorphic markers of paleobase levels allows the authors to establish a correlation between the three cave levels and Early-Middle Pleistocene terraces of the Arlanzón River. Fluvial incision, erosional lowering and eventually collapse sinkhole development, resulted in the formation of cave entrances, allowing human occupation from ca. 1.22 Myr until the caves and associated sinkholes became filled by the end of the Middle Pleistocene.

The following four papers deal with several geomorphological aspects related to highly soluble Tertiary evaporite formations in the Tajo and Ebro basins. Silva et al..... In a stretch of the Ebro Valley, Guerrero et al. document kilometre-scale subsidence depressions, thickened terrace and pediment deposits $(>50 \mathrm{~m})$ and intense gravitational deformation mainly related to interstratal glauberite and halite dissolution. The splendid exposures of dissolution-induced deformation affecting the evaporitic bedrock, including collapse breccias with a complete textural gradation from crackle packbreccias to chaotic floatbreccias, and karstic residues, may constitute a valuable surface analogue for prolific hydrocarbon reservoirs, as well as mineralizations associated with paleokarst formations. This work demonstrates for the first time subsidence phenomena related to dissolution of an exceptional glauberite unit, in which glauberite beds, up to $30 \mathrm{~m}$ thick, reach a cumulative thickness of $100 \mathrm{~m}$. Gutiérrez et al. investigate the origin and morpho-stratigraphic evolution of a playa-lake system developed on gypsiferous bedrock in the Ebro Basin. This area has been the focus of numerous paleolimnological investigations, probably lacking a good understanding of the geomorphic context. The authors, based on detailed geomorphological mapping, document a sequence of three lacustrine terraces and wind-fluted yardangs in the leeward sector. Radiocarbon dating of the intermediate terrace indicates an aggradation phase between $3.9 \mathrm{ka}$ and ca. $2 \mathrm{ka}$, followed by an excavation phase related to wind erosion ascribable to dry conditions. The estimated lowering rate by deflation of around $3 \mathrm{~mm} / \mathrm{yr}$ is comparable with those reported for paleolake basins in several arid regions of the world. The integration of morpho-stratigraphic and geophysical data supports a mixed karstic and eolian origin for the lake basin and allows ruling out previous interpretations involving the collapse of large bedrock cavities. Artieda analyses peculiar weathering landforms frequently found in the gypsum outcrops in the Ebro Tertiary Basin, including domes up to $1.1 \mathrm{~m}$ across (also designated as gypsum tumuli) and decimetre-scale blisters. These features are related to the volume increase and swelling of the most surficial weathered bedrock due to in situ dissolution and crystallization of gypsum in pores under a semiarid climate. The paper presents a thorough characterization integrating field observations and a comprehensive microscopic analysis, providing robust supporting evidence for a genetic model. 
The last six papers deal with different geomorphic processes with significant environmental implications and temporal changes in morphogenetic and sedimentary processes strongly influenced over the last decades by human activity. Díez-Herrero et al.... García-Ruiz et al. investigate debris flows triggered by a short-lasting and high intensity rainstorm event on steep slopes underlain by colluvium affected by a wildfire three weeks before. Indirect estimates of rainfall intensity reveal that the removal of the plant cover by burning involved a significant reduction in the rainfall threshold for initiating debris flows. This works illustrates how fires following the elimination of the vegetation may dramatically increase the sensitivity of slopes, so that ordinary rainfall events may lead to extraordinary erosion processes and geomorphic effects. Navas et al. assess rates and patterns of soil redistribution over the past 45 years in an internally drained karst catchment (ca. 80 ha) in the Pyrenees using fallout ${ }^{137} \mathrm{Cs}$ derived from nuclear testing. Areas of sediment gain and loss are defined by the geostatistical interpolation of ${ }^{137} \mathrm{Cs}$-derived soil redistribution point data (100x100 m grid). The authors, using a GIS and a detailed DEM estimate spatially distributed erosion and deposition rates for the whole catchment, covering around 80 ha. The comparison of these data with detailed geomorphological maps provides clues on the main factors controlling soil redistribution (e.g. cultivation) and reveals a clear linkage between erosion and depositional landforms. Gallart et al. analyse sediment dynamics in a humid mountain basin of the Eastern Pyrenees where badlands are the main sediment source and rainfall shows a high interannual variability. Erosion rates are obtained by different methods covering variable spatial and temporal scales; plot-scale measurements (up to 3 years long), monitoring of water discharge and suspended sediment loads in gauging stations (15 years), simulation of badland erosion with the KINEROS2 event model for 15 years. The comparison of the results and the assessment of the uncertainty and representativeness of the measurements, taking into account their temporal variability, indicate that sediment dynamics is mainly controlled by erosion processes in the badlands, unless infrequent severe events occur, which may activate sediment stores and other sediment sources. Moreover, they conclude that the long-term sediment production in these basins may be simulated with acceptable results if long records accounting for the high temporal variability are available. Del Río et al. analyse quantitatively the shoreline changes occurred over the period 1956-2008 in 58 sandy beaches in the micro-mesotidal and low energy south Atlantic Spanish coast comparing orthorectified aerial photographs. Additionally, in selected areas the evolution of beach profiles is studied by topographic monitoring (2000-2006). The observed spatialtemporal change patterns reveal that sediment supply, largely reduced in some sectors due to dam construction, is the main controlling factor. Other significant factors include nearshore bathymetry, as it influences wave action, and human alterations such as construction of transverse structures obstructing longshore drift and back beach development. A morphological and evolutionary classification of sandy beaches is proposed, which may be used for managing retreating beaches, a resource of great environmental and economic importance in the area. Bruschi et al., using sediment cores from eight estuaries in northern Spain and dated by ${ }^{210} \mathrm{~Pb}$ and ${ }^{137} \mathrm{Cs}$, document a general increase in the sedimentation rate during the last century. No relationship between this trend and rainfall data is found, but a good correspondence with several indicators of the human activities that contribute to modify the land surface (e.g. construction of new houses, GDP, cement consumption). The similarity in the temporal trends support the hypothesis proposed by the authors and already tested in other regions, whereby the activity of certain geomorphic processes has increased worldwide during the Anthropocene, mainly due to the impact caused by human activity on the 
ground surface and the consequent changes in the sensitivity and thresholds of geomorphic systems (i.e. global geomorphic change).

\section{Acknowledgements}

We are very grateful to all the referees for their indispensable and unselfish work that greatly contributed to the improvement of the quality of the papers.The Department of Environment and the Department of Science, Technology and University of the Aragón Government, as well as the Innovation Ministry of the Spanish Government (CGL201112465), provided financial support to organize the scientific meeting "Geomorphological Research in Spain" (Zaragoza, September, 2011). We thank the International Association of Geomorphologists (IAG), the Spanish Society of Geomorphology (SEG), and the Spanish Association of Quatetrnary Studies (AEQUA) for supporting the initiative. We are also sincerely grateful to Drs. Cinta Marín for helping with the preparation of the bibliometric data and supplementary material presented in this guest editorial.

\section{References}

Álvarez-Marrón, J., Hetzel, R., Niedermann, S., Menéndez, R., Marquínez, J., 2008. Origin, structure and exposure history of a wave-cut platform more than $1 \mathrm{Ma}$ in age at the coast of Northern Spain: A multiple cosmogenic nuclide approach. Geomorphology 93, 316-334.

Arche, A., Evans, G., Clavell, E., 2010. Some considerations on the initiation of the present SE Ebro river drainage system: Post- or pre-Messinian? Journal of Iberian Geology 36, 73-85.

Azañón, J.M., Azor, A., Pérez-Peña. J.V., Carrillo, J.M., 2005. Late Quaternary largescale rotational slides induced by river incision: The Arroyo de Gor area (Guadix basin, SE Spain). Geomorphology 69, 152-168.

Baena, R., Díaz del Olmo, F., 1997. Resultados plaeomagnéticos de la Raña del Hespérico Meridional (Montoro, Cordoba). Geogaceta 21, 31-34.

Bateman, M.D., Díez, A., 1999. Thermoluminiscence dates and palaeoenvironmental information of the Quaternary sand deposits, Tierra de Pinares. Catena 34, 277-291.

Beguería, S., 2006. Changes in land cover and shallow landslide activity: A case study in the Spanish Pyrenees. Geomorphology 74, 196-206.

Benito-Calvo, A., Pérez-González, A., 2007. Quantitative reconstruction of Late Cenozoic landscapes: a case study in the Sierra de Atapuerca (Burgos, Spain). Earth Surface Processes and Landforms 33, 196-208.

Benito-Calvo, A., Pérez-González, A., Magri, O., Meza, P., 2009. Assessing regional geodiversity: the Iberian Peninsula. Earth Surface Processes and Landforms 34, 1433-1445.

Benito, G., Sancho, C., Peña, J.L., Machado, M.J., Rhodes, E.J., 2010. Large-scale karst subsidence and accelerated fluvial aggradation during MIS6 in the NE Spain: climatic and paleohydrological implications. Quaternary Science Reviews 29, 26942704.

Bernat-Rebollal, M., Pérez-González, A., 2008. Inland aeolian deposits of the Iberian Peninsula: Sand dunes and clay dunes of the Duero Basin and the Manchega Plain. Palaeoclimatic considerations. Geomorphology 102, 207-220.

Con formato: Español
(España - alfab.
internacional)
Con formato: Español
(España - alfab.
internacional)
Con formato: Inglés
(Reino Unido)
Con formato: Inglés
(Reino Unido)

Con formato: Inglés

(Reino Unido)

Con formato: Inglés

(Reino Unido)

Con formato: Inglés

(Reino Unido) 
Borja, F., Zazo, C., Dabrio, C.J., Díaz del Olmo, F., Goy, J.L., Lario, J., 1999. Holocene eolian phases and human settlements along the Atlantic coast of southern Spain. The Holocene 93, 333-339.

Boulesteix, T., Hildenbrand, A., Gillot, P.Y., Soler, V., 2012. Eruptive response of oceanic islands to giant landslides: New insights from the geomorphologic evolution of the Teide-Pico Viejo volcanic complex (Tenerife, Canary). Geomorphology 138, 61-73.

Calaforra, J.M., Pulido-Bosch, A., 1999. Gypsum karst features as evidence of diapiric processes in the Betic Cordillera, Southern Spain. Geomorphology 29, 251-264.

Calaforra, J.M., Pulido-Bosch, A., 2003. Evolution of the gypsum karst of Sorbas (SE Spain). Geomorphology 50, 173-180.

Canals, M., Got, H., Juliá, R., Serra, J., 2006. Solution-collapse depressions and suspensates in the limnocrenic lake of Banyoles (NE Spain). Earth Surface Processes and Landforms 15, 243-254.

Carracedo, J.C., Rodríguez-Badiola, E., Soler, V., 1992. The 1730-1736 eruption of Lanzarote, Canary Islands: A long, high-magnitude basaltic fissure eruption. Journal of Volcanology and Geothermal Research 53, 239-250.

Carrasco, R.M., Pedraza, J., Domínguez-Villar, D., Villa, J., Willenbring, J.K., 2012. The plateau glacier in the Sierra de Béjar (Iberian Central System) during its maximum extent. Reconstruction and chronology. Geomorphology doi: 10.1016/j.geomorph.2012.03.019

Cendrero, A., Dramis, F., 1996. The contribution of landslides to landscape evolution in Europe. Geomorphology 15, 191-211.

Chueca-Cía, J., Julián-Andrés, A., Saz-Sánchez, M.A., Creus-Novau, J., López-Moreno, J.I., 2005. Responses to climatic changes since the Little Ice Age on Maladeta Glacier (Central Pyrenees). Geomorphology 68, 167-182.

Corominas, J., Moya, J., 1999. Reconstructing recent landslide activity in relation to rainfall in the Llobregat River basin, Eastern Pyrenees, Spain. Geomorphology 30, 79-93.

Cowton, T., Hughes, P.D., Gibbard, P.L., 2009. Palaeoglaciation of Parque Natural Lago de Sanabria, northwest Spain. Geomorphology 108, 282-291.

Delgado, J., Vicente, F., García-Tortosa, F., Alfaro, P., Estévez, A., López-Sánchez, J.M., Tomás, R., Mallorquí, J.J., 2011. A deep seated compound rotational rock slide and rock spread in SE Spain: Structural control and DInSAR monitoring. Geomorphology 129, 252-262.

Díaz del Olmo, F., Vallespí, E., Baena, R., Recio, J.M., 1989. Terrazas pleistocenas del Guadalquivir occidental. Geomorfología, suelos, paleosuelos y secuencia cultural. In: Díaz del Olmo, F., Rodríguez-Videl, J., (Eds.). El Cuaternario en Andalucía occidental. AEQUA Monograph 1, 67-86.

Ferrer, M., González de vallejo, L.I., García, J.C., Rodríguez, J.A., 2004. Pérdidas por terremotos e inundaciones en España durante el periodo 1987-2001 y su estimación para los próximos 30 años (2004-2033). IGME. Madrid, 126 p.

Finlayson, C., Giles-Pacheco, F., Rodríguez-Vidal, J., Fa, D.A., Gutiérrez-López, J.A., Santiago, A., Finlayson, G., Allue, E., Baena-Preysler, J., Cáceres, I., Carrión, J.S.,
Con formato: Inglés

(Reino Unido)

Con formato: Inglés

(Reino Unido)

Con formato: Inglés

(Reino Unido)

Con formato: Inglés

(Reino Unido)

Con formato: Español

(España - alfab.

internacional) 
Fernández-Jalvo, Y., Gleed-Owen, C.P., Jimenez-Espejo, F.J., López, P., LópezSáez, J.A., Riquelme, J.A., Sánchez-Marco, J.A., Giles-Guzman, F., Brown, K., Fuentes, N., Valarino, C.A., Villalpando, A., Stringer, C.B., Martínez-Ruiz, F., Sakamoto, T., 2006. Late survival of Neanderthals at the southernmost extreme of Europe. Nature 443, 850-853.

Flor, G., Flor-Blanco, G., 2006. Morphodynamic processes in the estuarine barrier of Guernica (Northern of Spain): problems and solutions for their management. J. Coast. Res. (Spec. Issue), SI 48, 41-48.

Font, I., 1983. Climatología de España y Portugal. Instituto Nacional de Meterorología. Madrid, 296 p.

Galve, J.P., Gutiérrez, F., Lucha, P., Bonachea, J., Remondo, J., Cendrero, A., Gutiérrez, M., Gimeno, M.J., Pardo, G., Sánchez, J.A., 2009. Sinkholes in the saltbearing evaporite karst of the Ebro River valley upstream of Zaragoza city (NE Spain). Geomorphological mapping and analysis as a basis for risk management. Geomorphology 108, 145-158.

García, A.F., Zhu, Z., Ku, T.L., Sanz de Galdeano, C., Chadwick, O.A., Chacón Montero, J., 2003. Tectonically driven landscape development within the eastern Alpujarran Corridor, Betic Corillera, SE Spain (Almería). Geomorphology 50, 83110.

García-Hidalgo, J.F., Temiño, J., Segura, M., 2007. Holocene aeolian development in central Spain; chronology, regional correlations and causal processes. Quaternary Science Reviews 26, 2661-2673.

García-Ruiz, J.M., 1999. La producción científica de la geomorfología española y su impacto, a través de las publicaciones periódicas. Instituto Pirenaico de Ecología, Zaragoza, $104 \mathrm{p}$.

García-Ruiz, J.M., Valero-Garcés, B.L., Martí-Bono, C., González-Samperiz, P., 2003. Asynchroneity of maximum glaciar advances in the central Spanish Pyrenees. Journal of Quaternary Science 18, 61-72.

García-Ruiz, J.M., Beguería, S., Alatorre, L.C., Puigdefábregas, J., 2010. Land cover changes and shallow landsliding in the flysch sector of the Spanish Pyrenees. Geomorphology 124, 250-259.

García-Tortosa, F.J., Alfaro, P., Sanz de Galdeano, C., Galindo-Zaldívar, J., 2011. Glacis geometry as a geomorphic marker of recent tectonics: The Guadix-Baza basin (South Spain). Geomorphology 125, 517-529.

Gelabert, B., Fornós, J.J., Gómez-Pujol L., 2003. Geomorphological characteristics and slope processes associated with different basins: Mallorca (Western Mediterranean). Geomorphology 52, 253-267.

Gibbons, W., Moreno, T., 2002 (Eds.). The Geology of Spain. Geological Society, London, 649 p.

González-Díez, A., Remondo, J., Díaz de Terán, J.R., Cendrero, A., 1999. A methodological approach for the analysis of the temporal occurrence and triggering factors of landslides. Geomorphology 30, 95-113.

Gómez-Ortiz, A., Palacios, C., Palade, B., Vázquez-Selem, L., Salvador-Franch, F., 2012. The deglaciation of the Sierra Nevada (Southern Spain). Geomorphology 159160, 93-105.
Con formato: Inglés

(Reino Unido)

Con formato: Inglés

(Reino Unido)

Con formato: Español

(España - alfab.

internacional)

Con formato: Inglés

(Reino Unido) 
Goy, J.L., Zazo, C., Rodríguez-Vidal, J., 1994. Cordilleras Béticas-Islas Baleares. In: 4 - Gutiérrez-Elorza, M. (Ed.). Geomorfología de España. Rueda. Madrid,-123-157.

Goy, J.L., Zazo, C., Dabrio, C.J., 2003. A beach-ridge progradation complex reflecting periodical sea-level and climate variability during the Holocene (Gulf of Almería, Western Mediterranean). Geomorphology 50, 251-268.

Goy, J.L., Zazo, C., 2005. El litoral. In: Martín-Serrano, A. (Ed.). Mapa Geomorfológico de España y del Margen Continental escala 1:1,000,000. IGME. Madrid, pp. 137-156.

Gracia, F.J., Gutiérrez, F., Gutiérrez, M., 2003. The Jiloca karst polje-tectonic graben (Iberian Range, NE Spain). Geomorphology 52, 215-231.

Guerrero, J., Gutiérrez, F., Galve, J.P., 2012b. Large depressions, thickened terraces, and gravitational deformation in the Ebro River valley (Zaragoza area, NE Spain): Evidence of glauberite and halite interstratal karstification. Geomorphology doi: 10.1016/j.geomorph.2012.06.024

Guerrero, J., Gutiérrez, F., García-Ruiz, J.M., Galve, J.P., Lucha, P., Carbonel, D., Bonachea, J., 2012a. Landslide map of the upper Gallego Valley (central Spanish Pyrenees). Journal of Maps, in press. (NO TIENE ASIGNADO DOI?)

Gutiérrez, F., Gutiérrez, M., Sancho, C., 1998. Geomorphological and sedimentological analysis of a catastrophic flash flood in the Arás drainage basin (Central Pyrenees, Spain). Geomorphology 22, 265-283.

Gutiérrez, F., Ortuño, M., Lucha, P., Guerrero, J., Acosta, E., Coratza, P., Piacentini, D., Soldati, M., 2008a. Late Quaternary episodic displacement on a sackung scarp in the central Spanish Pyrenees. Secondary paleoseismic evidence?. Geodinámica Acta 21, 187-202.

Gutiérrez, F., Gutiérrez, M., Gracia, F.J., McCalpin, J.P., Lucha, P., Guerrero, J., 2008b. Plio-Quaternary extensional seismotectonics and drainage network development in the central sector of the Iberian Range (NE Spain). Geomorphology 102, 1, 21-42.

Gutiérrez, F., Linares, R., Roqué, C., Zarroca, M., Rosell, J., Galve, J.P., Carbonell, D., 2012. Investigating gravitational grabens related to lateral spreading and evaporite dissolution subsidente by means of detailed mapping, trenching, and electrical resistivity tomography (Spanish Pyrenees). Lithosphere 10.1130/L202.1

Gutiérrez, M., 1994. (Ed.). Geomorfología de España. Rueda. Madrid, 526 p.

Gutiérrez, M., 2001. Geomorfología climática. Omega. Barcelona, 642 p.

Gutiérrez, M., 2005. Climatic Geomorphology. Elsevier. Amsterdam, 760 p.

Gutiérrez, M., 2008. Geomorfología. Pearson-Prentice Hall. Madrid, 920 p.

Gutiérrez, M., 2013. Geomorphology. Balkema. Rotterdam, in press.

Gutiérrez, M., Peña, J.L., 1977. Las acumulaciones periglaciares del Macizo del Tremedal (Sierra de Albarracín). Boletín Geológico y Minero 92, 101-110.

Gutiérrez, M., Peña, J.L., 1979. El karst de Villar del Cobo (Sierra de Albarracín). Estudios Geológicos 35, 651-654.

Gutiérrez, M., Peña, J.L., 1994. Cordillera Ibérica. In: Geomorfología de España. In. Gutiérrez, M. (Ed.). Rueda, Madrid, pp. 251-286.
Con formato: Inglés

(Reino Unido)

\begin{tabular}{l}
$\begin{array}{l}\text { Con formato: Español } \\
\text { (España - alfab. }\end{array}$ \\
$\begin{array}{l}\text { Con formato: Inglés } \\
\text { (Reino Unido) }\end{array}$ \\
\hline
\end{tabular}

Con formato: Inglés

(Reino Unido)

Con formato: Inglés

(Reino Unido)

Con formato: Inglés

(Reino Unido)

Con formato: Español

(España - alfab.

internacional)

Con formato: Inglés

(Reino Unido) 
Gutiérrez-Elorza, M., Desir, G., Gutiérrez-Santolalla, F., 2002. Yardangs in the semiarid central sector of the Ebro Depression (NE Spain). Geomorphology 44, 155-170.

Gutiérrez-Elorza, M., Desir, G., Gutiérrez-Santolalla, F., Marín, C., 2005. Origin and evolution of playas and blowouts in the semiarid zone of Tierra de Pinares (Duero Basin, Spain). Geomorphology 72, 177-192.

Gutiérrez-Elorza, M., Lucha, P., Gutiérrez, F., Moreno, A., Guerrero, J., MartínSerrano, A., Nozal, F., Desir, G., Marín, G., 2010. Are talus flatiron sequences in Spain climate-controlled landforms?. Zeitschrift für Geomorphologie 54, 243-252.

Harvey, A.M., Wells, S.G., 1987. Response of Quateranry fluvial systems to differential epeirogenic uplift: Aguas and Feos River systems, southeast Spain. Geology 15, 689-693.

Harvey, A.M., Silva, P.G., Mather, A.E., Goy, J.L., Stokes, M., Zazo, C., 1999. The impact of Quaternary sea-level and climatic change on coastal alluvial fans in the Cabo de Gata ranges, southeast Spain. Geomorphology 28, 1-22.

Hürlimann, M., Martí, J., Ledesma, A., 2004. Morphological and geological aspects related to large slope failures on oceanic islands. The huge La Orotova landslides on Tenerife, Canary Islands. Geomorphology 62, 143-158.

IGN, 1995. Atlas Nacional de España. Ministerio de Obras Públicas, Transportes y Medio Ambiente. Madrid, 311.

Jiménez-Sánchez, M., Rodríguez-Rodríguez, L., García-Ruiz, J.M., Domínguez-Cuesta, M.J., Farias, P., Valero-Garcés, B., Moreno, A., Rico, M., Valcárcel, M. 2012. A review of glacial geomorphology and chronology in northern Spain: Timing and regional variability during the last glacial cycle. Geomorpholgy doi: 10.1016/j.geomorph.2012.06.009

Lario, J., Zazo, C., Dabrio, C.J., Somoza, L., Goy, J.L., Bardají, T., Silva, P.G., 1995. Record of recent Holocene sediment input on spit bars and deltas of South Spain. Journal of Coastal Research special issue 17, 241-245.

Lewis, C.J., McDonald, E.V., Sancho, C., Peña, J.L., Rhodes, E.J., 2009. Climatic implications of correlated Upper Pleistocene glacial and fluvial deposits on the Cinca and Gállego Rivers (NE Spain) based on OSL dating and soil stratigraphy. Global and Planetary Change 67, 141-152.

Lhenaff, R., 1986. Les grans poljés des Cordilleres Bétriques andalouses et leurs rapports avec l’organisation endokarstique. Karstologia memoires 1, 101-112.

Llasat, M.C., Llasat-Botija, M., Rodríguez, A., Lindbergh, S., 2010. Flash floods in Catalonia: a recurrent situation. Advances in Geosciences 26, 105-111.

López-Vicente, M., Navas, A., Machín, J., 2009. Geomorphic mapping in endorheic catchments in the Spanish Pyrenees: An integrated GIS analysis of karstic features. Geomorphology 111, 38-47.

Lucha, P., Gutiérrez, F., Galve, J.P., Guerrero, J., 2012. Geomorphic and stratigraphic evidence of incision-induced halokinetic uplift and dissolution subsidence in transverse drainages crossing the evaporite-cored Barbastro-Balaguer Anticline (Ebro Basin, NE Spain). Geomorphology 171-172, 154-172.
Con formato: Inglés

(Reino Unido)

Con formato: Español

(España - alfab.

internacional)

Con formato: Inglés

(Reino Unido)

$\begin{aligned} & \text { Con formato: Inglés } \\ & \text { (Reino Unido) }\end{aligned}$
$\begin{aligned} & \text { Con formato: Español } \\ & \text { (España - alfab. } \\ & \text { internacional) }\end{aligned}$

Con formato: Español

(España - alfab.

internacional) 
Maher, E., Harvey, A.M., 2008. Fluvial system response to tectonically induced baselevel change during the late-Quaternary: The Río Alias, southeast Spain. Geomorphology 100, 180-192.

Maher, E., Harvey, A.M., France, D., 2007. The impact of a major Quaternary river capture on the alluvial sediments of a beheaded river system, the Río Alias, SE Spain. Geomorphology 84, 344-356.

Martí, C., Valero, B., García-Ruiz, J.M., 1997. Large, historical debris flows in the central spanish Pyrenees. Physics and Chemistry of the Earth 22, 381-385.

Martí, J., Planagumà, L., Adelina, G., Canal, E., Pedrazzi, D., 2011. Complex interaction between Strombolian and phreatomagmatic eruptions in the Quaternary monogenetic volcanism of the Catalan Volcanic Zone (NE of Spain). Journal of Volcanology and Geothermal Research 201, 178-193.

Martín-González, F., 2009. Cenozoic tectonic activity in a Variscan basement: Evidence from geomorphological markers and structural mapping (NW Iberian Massif). Geomorphology 107, 210-225.

Martín-Serrano, A. 1991. La definición y el encajamiento de la red fluvial actual sobre el Macizo Hespérico en el marco de su geodinámica alpina. Revista de la Sociedad Geológica de España 4, 337-351.

Martín-Serrano, A., 2005. Mapa Geomorfológico de España y del Margen Continental 1:1,000,000. IGME. Madrid, 232 p.

Martín-Vide, J., 2002. Las lluvias máxima diarias. In: Ayala-Carcedo, F., Olcina, J. (Eds.). Riesgos Naturales. Ariel Ciencia. Barcelona, 913-920.

Masson, D.G., Watts, A.B., Gee, M.J.R., Urgeles, R., Mitchell, N.C., Le Bas, T.C., Canals, M., 2002. Slope failures on the flanks of the western Canary Islands. Earth Science Reviews 57, 1-35.

Mather A.E., 2000. Adjustment of a drainage network to capture induced base-level change: an example from the Sorbas Basin, SE Spain. Geomorphology 34, 271-289.

Mather, A.E., Stokes, M., 2003. Long-term landscape development in southern Spain. Geomorphology 50, 1-2.

Menéndez, I., Silva, P.G., Martín-Betancor, M., Pérez-Torrado, F.J., Guillou, H., Scaillet, S., 2008. Fluvial dissection, isostatic uplift, and geomorphological evolution of volcanic islands (Gran Canaria, Canary Islands, Spain). Geomorphology 102, 189-203.

Milanovic, P., 2000. Geological engineering in karst. Zebra. Beograd, 347 p.

Molina, E., García, J., Vicente, M.A., 1997. Paleoweathering profiles developed on the Iberian Hercynian Basement and their relationship to the oldest Tertiary surface in central and western Spain. In: Widdowson, W. (Ed.). Paleosurfaces: recognition, reconstruction and paleoenvironmental interpretation. Geological Society, London 120, pp. 175-186.

Molina-Ballesteros, E., Cantano Martín, M., 2002. Study of weathering processes developed on old piedmont surfaces in Western Spain: new contributions to the interpretation of the "Raña” profiles. Geomorphology 42, 179-292.

Moro-Martín, A., 2012. Spanish changes are scientific suicide. Nature 482, doi: $10.1038 / 482277^{a}$

\section{Con formato: Inglés \\ (Reino Unido)}

Con formato: Inglés

(Reino Unido)

Con formato: Inglés

(Reino Unido)

Con formato: Español

(España - alfab.

internacional)

Con formato: Español

(España - alfab.

Con formato: Español

(España - alfab.

internacional)

Con formato: Español

(España - alfab.

internacional)

Con formato: Inglés

(Reino Unido)

Con formato: Inglés

(Reino Unido)

Con formato: Inglés

(Reino Unido)

Con formato: Inglés

(Reino Unido) 
Ortega, J.A., Garzón-Heydt, G., 2009. Geomorphological and sedimentological analysis of flash-flood deposits. The case of the 1997 Rivillas flood (Spain). Geomorphology 112, 1-14.

Pagés-Valcarlos, J.L., 2000. Origen y evolución geomorfológica de las rías atlánticas de Galicia. Revista de al Sociedad Geológica de España 13, 393-403.

Pain, E., 2012. Research cuts will cause exodus from Spain. Science 336, 139-140.

Perea, H., Masana, E., Santanach, P., 2012. An active zone characterized by slow normal faults, the Northwestern margin of the Valencia trough (NE Iberia): a review. Journal of Iberian Geology 38, 31-52.

Pérez-González, A., Cabra, P., Martín-Serrano, A. 1989 (Eds.). Mapa del Cuaternario de España 1:1,000,000. ITGE. Madrid, 279 p.

Pinyol, N.M., Alonso, E.E., Corominas, J., Moya, J., 2012. Canelles landslide: modelling rapid drawdown and fast potential sliding. Landslides 9, 33-51.

Plater, A.J., Lang, A., 2008. Fluvial systems: Dynamics, morphology and the sedimentary record. Geomorphology 100, 1-2.

Reicherter, K.R., Jabaloy, A., Galindo-Zaldíbar, J., Ruano, P., Becker-Heidmann, P., Morales, J., Reiss, S., González-Lodeiro, F., 2003. Repeated paleoseismic activity of the Ventas de Zafarraya fault (S Spain) and its relation with the 1884 Andalusian earthquake. International Journal of Earth Sciences 92, 912-922.

Remondo, J., Bonachea, J., Cendrero, A., 2005. A statistical approach to landslide risk modelling at basin scale: from landslide susceptibility to quantitative risk assessment. Landslides 2, 321-328.

Rodríguez-González, A., Fernández-Turiel, J.L., Pérez-Torrado, F.J., Paris, R., Gimeno, D., Carracedo, J.C., Aulinas, M., 2012. Factors controlling the morphology of monogenetic basaltic volcanoes: The Holocene volcanism of Gran Canaria (Canary Islands, Spain). Geomorphology 136, 31-44.

Roqué, C., Linares, R., Rodríguez, R., Zarroca, M., 2011. Granite caves in the northeast of the Iberian Peninsula: Artificial hypogea versus tafoni. Zeitschrift für Geomorphologie 55, 341-364.

Rosell, J., Linares, R., Fité, F., Roqué, C., Llompart, C., Losantos, M., 2010. Montclús. Misteriós naixement i desaparició d’un poble. Institut Geològic de Catalunya. Barcelona, $111 \mathrm{p}$.

Sanjaume, E., Gracia, F.J., 2011 (Eds.). Las dunas de España. Sociedad Española de Geomorfología. Madrid, 747 p.

Serrano, E., de Sanjosé, J.J., González-Trueba, J.J., 2010. Rock glacier dynamics in marginal periglacial environments. Earth Surface Processes and Landforms 35, 1302-1314.

Silva, P.G., Goy, J.L., Zazo, C., Bardají, T., 2003. Fault-generated mountain fronts in southeast Spain: geomorphologic assessment of tectonic and seismic activity. Geomorphology 50, 203-225.

Silva, P.G., Bardají, T., Calmel-Ávila, M., Goy, J.L., Zazo, C., 2008. Transition from alluvial to fluvial systems in the Guadalentín Depression (SE Spain) during the Holocene: Lorca Fan versus Guadalentín River. Geomorphology 100, 140-153.
Con formato: Español

(España - alfab.

internacional)

Con formato: Inglés

(Reino Unido)

Con formato: Inglés

(Reino Unido)

Con formato: Inglés

(Reino Unido)

Con formato: Español

(España - alfab.

internacional) 
Silva, P.G., López-Recio, M., Tapias, F., Roquero, E., Morín, J., Rus, I., Carrasco García, P., Rodriguez-Pascua, M.A., Pérez-López, R. 2012. Stratigraphy of the Arriaga Palaeolithic sites. Implications for the geomorphological evolution recorded by thickened fluvial sequences within the Manzanares River valley (Madrid Neogene Basin, Central Spain). Geomorphology

Urgelés, R., Canals, M., Baraza, J., Alonso, B., Masson, D.G., 1997. The most recent megaslides of the Canary Islands: the El Golfo Debris Avalanche and the Canary Debris Flow, west El Hierro Island. Journal of Geophysical Research 102, 2030520323.

Vázquez-Urbez, M., Pardo, G., Arenas, C., Sancho, C., 2011. Fluvial diffluence episodes reflected in the Pleistocene tufa deposits of the River Piedra (Iberian Range, NE Spain). Geomorphology 125, 1-10.

Vera, J.A., 2004 (Ed.). Geología de España. Sociedad Geológica de España - IGME. Madrid, $884 \mathrm{p}$.

Vilaplana, J.M., 2008. Los riesgos naturales en Cataluña. Generalitat de Catalunya. Barcelona, 226 p.

White, S., García-Ruiz, J.M., 1998. Extreme erosional events and their role in mountain areas of Northern Spain. Ambio 27, 4, 300-305.

White, S., García-Ruiz, J.M., Martí, C., Valero, B., Errea, M.P., Gómez-Villar, A., 1997. The 1996 Biescas campsite disaster in the central Spanish Pyrenees and its temporal and spatial context. Hydrological Processes 11, 1797-1812.

Whitfiled, E., Harvey, A.M., 2012. Interaction between the controls on fluvial system development: tectonics, climate, base level and river capture. Rio Alias, Southeast Spain. Earth Surface Processes and Landforms 37, 1387-1397.

Zarroca, M., Linares, R., Bach, J., Roqué, C., Moreno, V., Front, Ll., Baixeras, C., 2012. Integrated geophysics and soil gas profiles as a tool to characterize active faults: The Amer fault example (Pyrenees, NE Spain). Environmental Earth Sciences doi: 10.1007/s12665-012-1537-y.

Zazo, C., Dabrio, C.J., Borja, F., Goy, J.L., Lezine, A.M., Lario, J., Polo, M.D., Hoyos, M., Boersma, J.R., 1999. Pleistocene and Holocene eolian facies along the Huelva coast (southern Spain): climatic and neotectonic implication. Geologie en Mijnbouw 77, 209-224.

Zazo, C., Goy, J.L., Dabrio, C.J., Bardají, T., Hillaire-Marcel, C., Ghaleb, B., González-Delgado, J.A., Soler, V., 2003. Pleistocene marine terraces of the Spanish Mediterranean and Atlantic coast: record of coastal uplift, sea level highstands and climate changes. Marine Geology 194, 103-133.

Zazo, C., Goy, J.L., Dabrio, C.J., González-Delgado, J., Bardají, T., Hillaire-Marcel, C., Cabero, A., Ghaleb, B., Borja, F., Silva, P.G., Roquero, E., Soler, V. 2012. Retracing the Quaternary history of sea level on Spanish Mediterranean-Atlantic coasts: A geomorphological and sedimentological approach. Geomorphology

$$
\Delta
$$

Francisco Gutiérrez

University of Zaragoza, Spain
Con formato: Inglés

(Reino Unido)

Con formato: Español

(España - alfab.

internacional)

Con formato: Inglés

(Reino Unido)

Con formato: Español

(España - alfab.

internacional)

Con formato: Inglés

(Estados Unidos)

Con formato: Inglés

(Reino Unido) 
Antonio Cendrero

University of Cantabria, Spain

Adrian Harvey

University of Liverpool, UK

José María García-Ruiz

Pyrenean Institute of Ecology (CSIC), Spain

Pablo Silva

| University of Salamanca, Spain

I.

\section{Figure captions}

\begin{tabular}{|l|}
\hline $\begin{array}{l}\text { Con formato: Inglés } \\
\text { (Reino Unido) }\end{array}$ \\
\hline $\begin{array}{l}\text { Con formato: Inglés } \\
\text { (Reino Unido) }\end{array}$ \\
\hline $\begin{array}{l}\text { Con formato: Inglés } \\
\text { (Reino Unido) }\end{array}$ \\
\hline
\end{tabular}

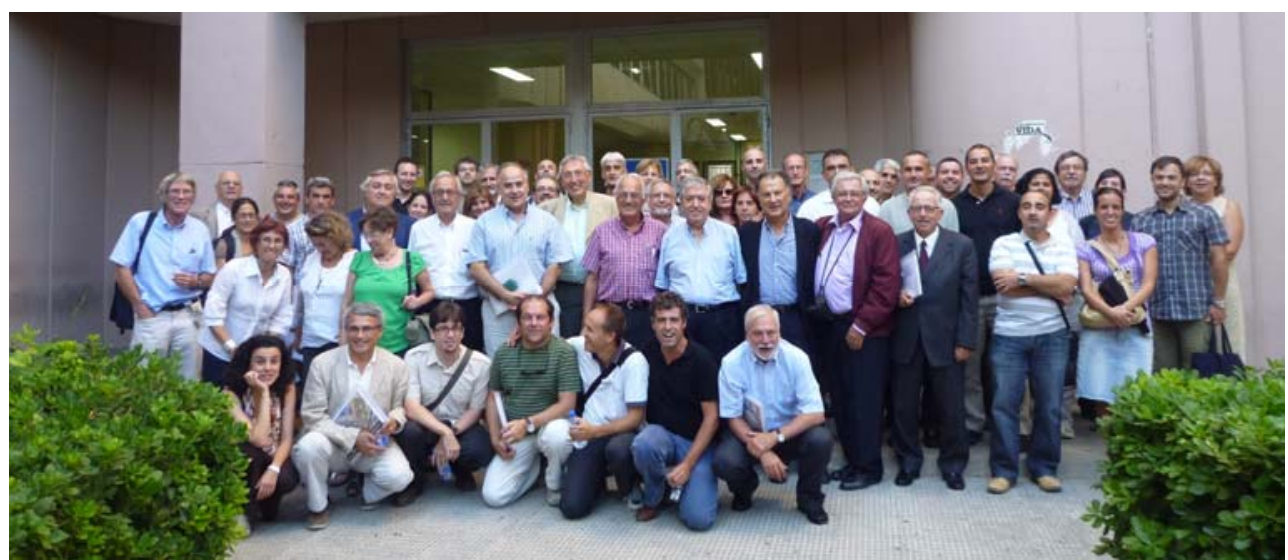

Figure 1. Photograph taken the first day of the meeting "Geomorphological research in Spain” (Zaragoza, September 8-9, 2011) with Mateo Guttierrez (second line, sixth from the left) and most of the participants. 


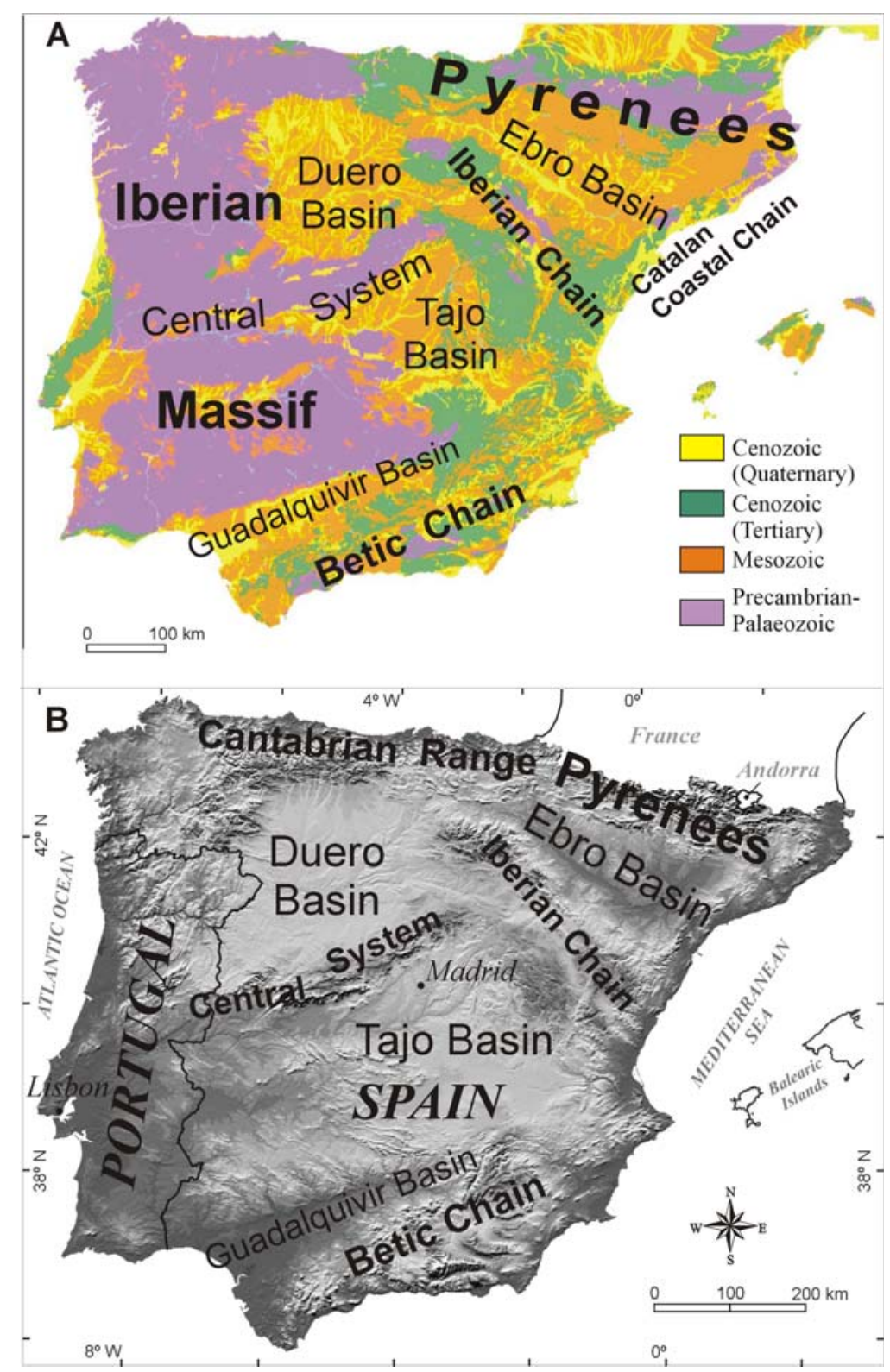




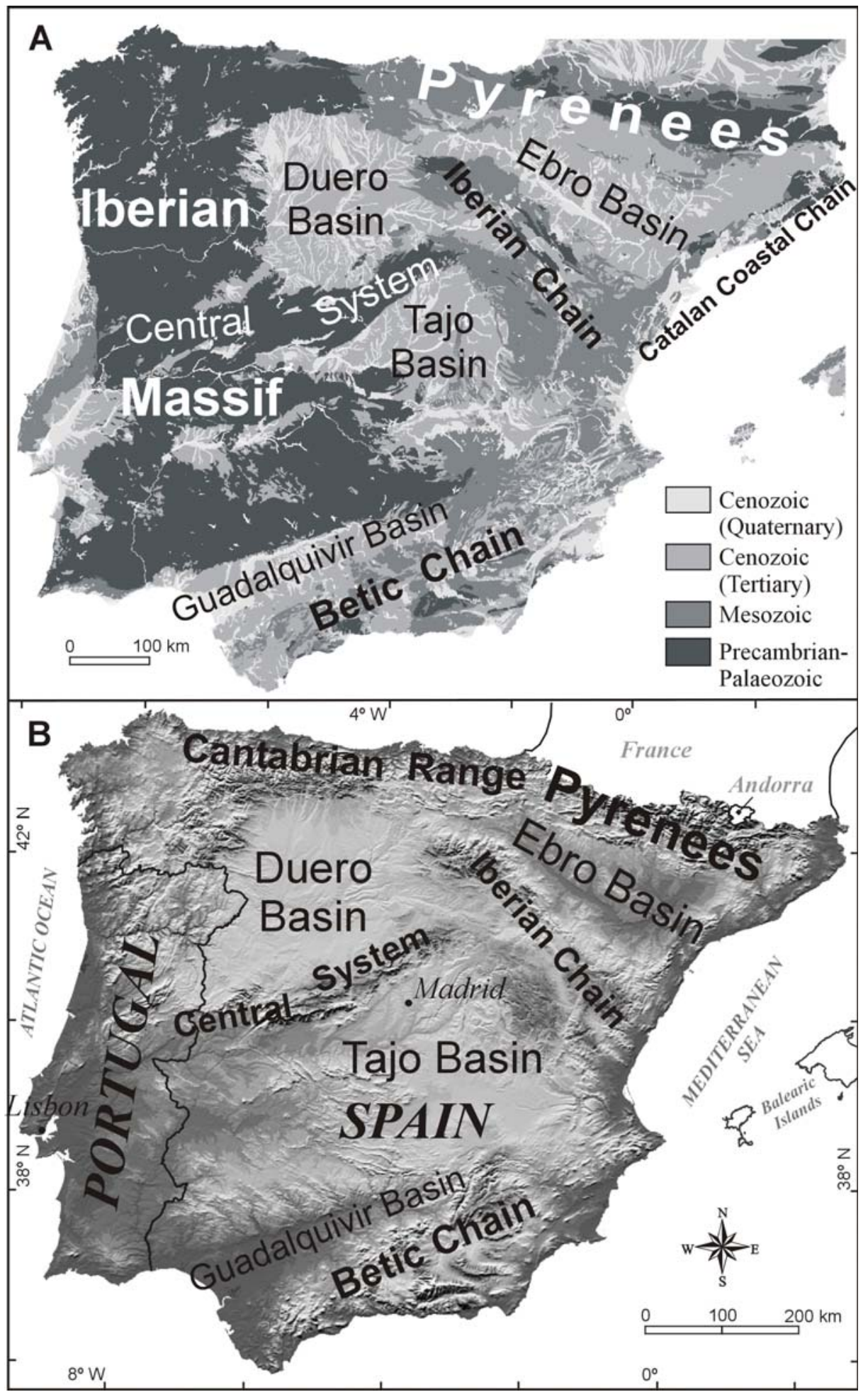

Figure 2. Geological map (A) and shaded relief model (B) of mainland Spain (elaborated by Alfonso Benito). 


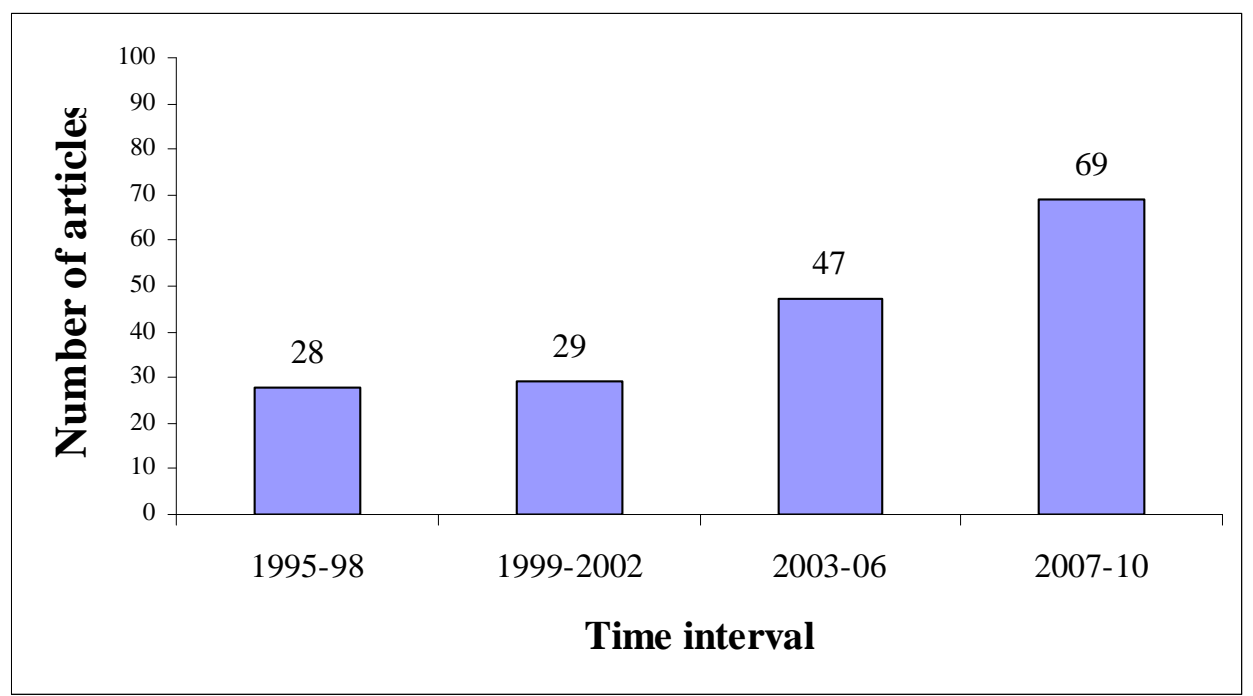

Figure 3. Histogram showing the number of papers dealing with the geomorphology of Spain published in Geomorphology between 1995 and 2010, grouped into 4-years-long periods. 


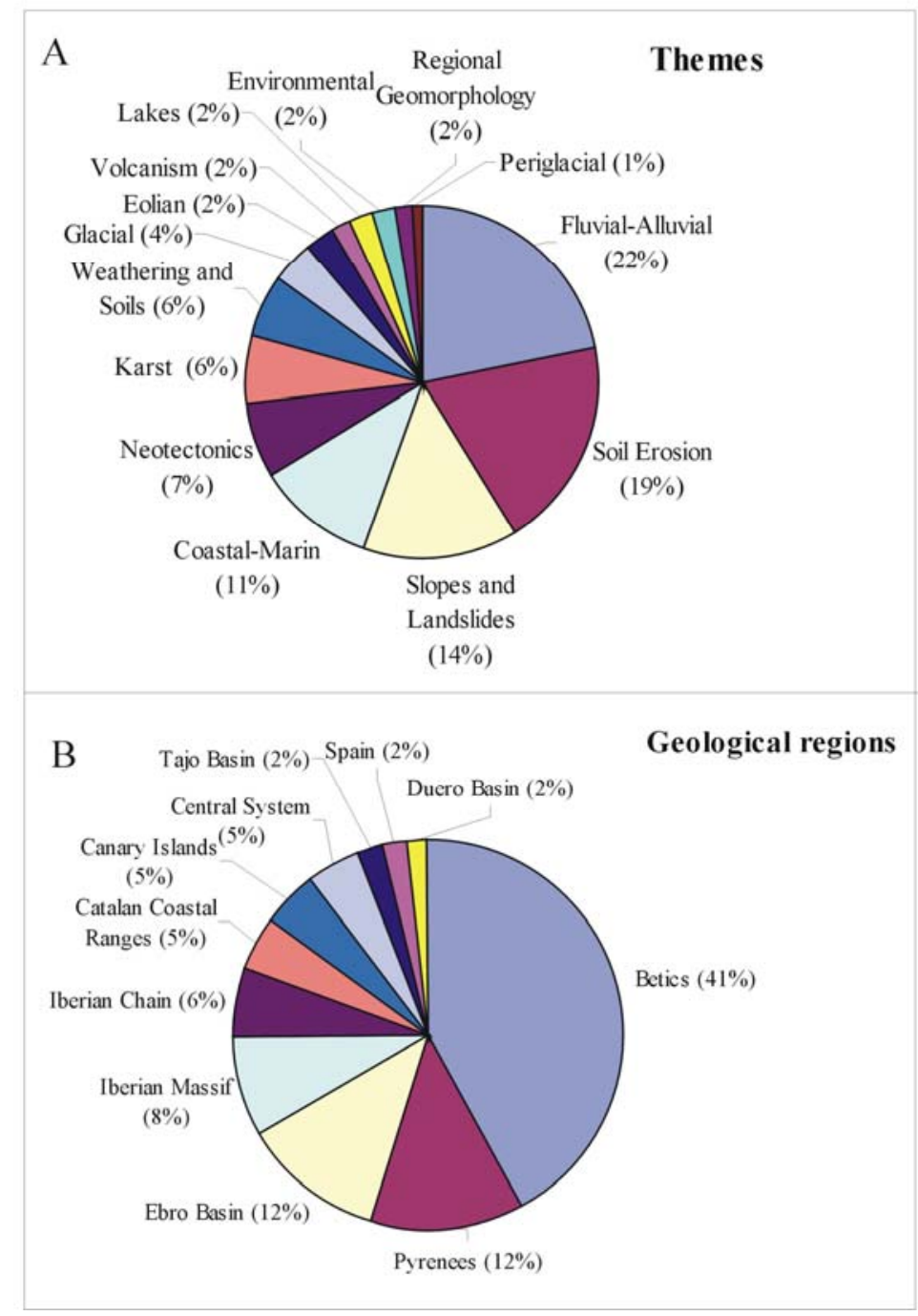

Figure 4. Percentage of papers dealing with Spain published in the journal Geomorphology according to their thematic (A) and geographical ascription (B). The geographical zones correspond to the main geological units of Spain. 
SPECIAL ISSUE

\section{Geomorphology in Spain}

Special issue in honour of Prof. Mateo Gutiérrez

Guest editors:
A. Cendrero ${ }^{\mathrm{a}}$, A. Harvey ${ }^{\mathrm{b}}$, J.M. García-Ruiz ${ }^{\mathrm{c}}$, P.G. Silva ${ }^{\mathrm{d}}$, F. Gutiérrez ${ }^{\mathrm{e}}$
${ }^{a}$ Departamento de Ciencias de la Tierra y Físca de la Materia Condensada, Universidad de Cantabria, Spain
${ }^{\mathrm{b}}$ Department of Geography, University of Liverpool, UK
c Instituto Pirenaico de Ecología, Consejo Superior de Investigaciones Científicas, Spain
${ }^{\text {d }}$ Departamento de Geología, Universidad de Salamanca, Spain
e Departamento de Ciencias de la Tierra, Universidad de Zaragoza, Spain

\section{CONTENTS}

Editorial: Geomorphological research in Spain

F. Gutiérrez, A. Harvey, A. Cendrero, J.M. García-Ruiz, P.G. Silva

1. Geomorphology of the Iberian Continental Margin

A. Maestro, J. López-Martínez, E. Llave, F. Bohoyo, J. Acosta, F.J. Hernández-Molina, A. Muñoz, G. Jané

2. Retracing the Quaternary history of sea level on Spanish Mediterranean-Atlantic coasts: A geomorphological and sedimentological approach

C. Zazo, J.L. Goy, C.J. Dabrio, J. González-Delgado, T. Bardají, C. Hillaire-Marcel, A. Cabero, B. Ghaleb, F. Borja, P.G. Silva, E. Roquero, V. Soler

3. A review of glacial geomorphology and chronology in northern Spain: Timing and regional variability during the last glacial cycle

M. Jiménez-Sánchez, L. Rodríguez-Rodríguez, J.M. García-Ruiz, M.J. DomínguezCuesta, P. Farias, B. Valero-Garcés, A. Moreno, M. Rico, M. Valcárcel

4. Quaternary glacial evolution in the Central Cantabrian Mountains (Northern Spain).

E. Serrano, J.J. González-Trueba, R. Pellitero, M. González-García, M. Gómez-Lende

5. The plateau glacier in the Sierra de Béjar (Iberian Central System) during its maximum extent. Reconstruction and chronology

R.M. Carrasco, J. Pedraza, D. Domínguez-Villar, J. Villa, J.K. Willenbring

6. Subsurface initiation of tafoni in granite terrains - Geophysical evidence from NE Spain

C. Roqué, M. Zarroca, R. Linares

7. The nature, timing and controls of the Quaternary development of the Río Bergantes, Ebro basin, northeast Spain

R.G. Whitfield, M.G. Macklin, P.A. Brewer, A. Lang, B. Mauz, E. Whitfield 
8. Evolution of multilevel caves in the Sierra de Atapuerca (Burgos, Spain) and its relation to human occupation

A.I. Ortega, A. Benito-Calvo, A. Pérez-González, M.A. Martín-Merino, R. PérezMartínez, J.M. Parés, A. Aramburu, J.L. Arsuaga, J.M. Bermúdez de Castro, E. Carbonell

9. Stratigraphy of the Arriaga Palaeolithic sites. Implications for the geomorphological evolution recorded by thickened fluvial sequences within the Manzanares River valley (Madrid Neogene Basin, Central Spain)

P.G. Silva, M. López-Recio, F. Tapias, E. Roquero, J. Morín, I. Rus, P. CarrascoGarcía, M.A. Rodriguez-Pascua, R. Pérez-López

10. Large depressions, thickened terraces, and gravitational deformation in the Ebro River valley (Zaragoza area, NE Spain): Evidence of glauberite and halite interstratal karstification

J. Guerrero, F. Gutiérrez, J.P. Galve

11. Late Holocene evolution of playa lakes in the central Ebro depression based on geophysical surveys and morpho-stratigraphic analysis of lacustrine terraces

F. Gutiérrez, B. Valero-Garcés, G. Desir, P. González Sampériz, M. Gutiérrez, R. Linares, M. Zarroca, A. Moreno, J. Guerrero, C. Roqué, L.J. Arnold, M. Demuro

12. Morphology and micro-fabrics of weathering features on gypsum exposures in a semiarid environment (Ebro Tertiary Basin, NE Spain)

O. Artieda

13. A review of dendrogeomorphological research applied to flood risk analysis in Spain.

A. Díez-Herrero, J.A. Ballesteros, V. Ruiz-Villanueva, J.M. Bodoque

14. Fire-related debris flows in the Iberian Range, Spain.

J.M. García-Ruiz, J. Arnáez, A. Gómez-Villar, L. Ortigosa, N. Lana-Renault

15. Assessing soil redistribution in a complex karst catchment using fallout ${ }^{137} \mathrm{Cs}$ and GIS

A. Navas, M. López-Vicente, L. Gaspar, J. Machín

16. Short- and long-term studies of sediment dynamics in a small humid mountain Mediterranean basin with badlands

F. Gallart, N. Pérez-Gallego, J. Latron, G. Catari, N. Martínez-Carreras, G. Nord

17. Shoreline change patterns in sandy coasts. A case study in SW Spain

L. Del Río, F.J. Gracia, J. Benavente

18. Analysis of geomorphic systems' response to natural and human drivers in northern Spain: Implications for global geomorphic change

V.M. Bruschi, J. Bonachea, J. Remondo, J. Gómez-Arozamena, V. Rivas, G. Méndez, J.M. Naredo, Cendrero, A. 
